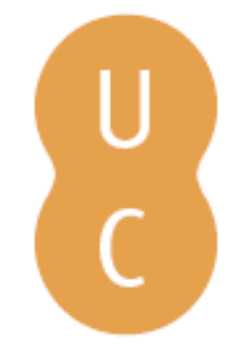

\title{
pommalina
}

\section{Pyrolysis gas chroma tography: mass spectrometry analysis for the estimation of pig bone age for forensic application}

\author{
Autor(es): $\quad$ Raja, S.; Stuart, B. H.; Thomas, P. S.; O’Brien, C. \\ Publicado por: Imprensa da Universidade de Coimbra; International Academy of Legal \\ URL \\ persistente: URI:http://hdl.handle.net/10316.2/31705 \\ DOI: $\quad$ DOI:http://dx.doi.org/10.14195/978-989-26-0173-1_1 \\ Accessed : $\quad$ 26-Apr-2023 11:34:24
}

A navegação consulta e descarregamento dos títulos inseridos nas Bibliotecas Digitais UC Digitalis, UC Pombalina e UC Impactum, pressupõem a aceitação plena e sem reservas dos Termos e Condições de Uso destas Bibliotecas Digitais, disponíveis em https://digitalis.uc.pt/pt-pt/termos.

Conforme exposto nos referidos Termos e Condições de Uso, o descarregamento de títulos de acesso restrito requer uma licença válida de autorização devendo o utilizador aceder ao(s) documento(s) a partir de um endereço de IP da instituição detentora da supramencionada licença.

Ao utilizador é apenas permitido o descarregamento para uso pessoal, pelo que o emprego do(s) título(s) descarregado(s) para outro fim, designadamente comercial, carece de autorização do respetivo autor ou editor da obra.

Na medida em que todas as obras da UC Digitalis se encontram protegidas pelo Código do Direito de Autor e Direitos Conexos e demais legislação aplicável, toda a cópia, parcial ou total, deste documento, nos casos em que é legalmente admitida, deverá conter ou fazer-se acompanhar por este aviso.

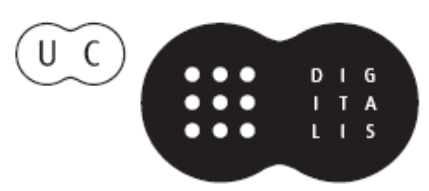




\section{Duarte Nuno Vieira Anthony Busuttil \\ Denis Cusack • Philip Beth}
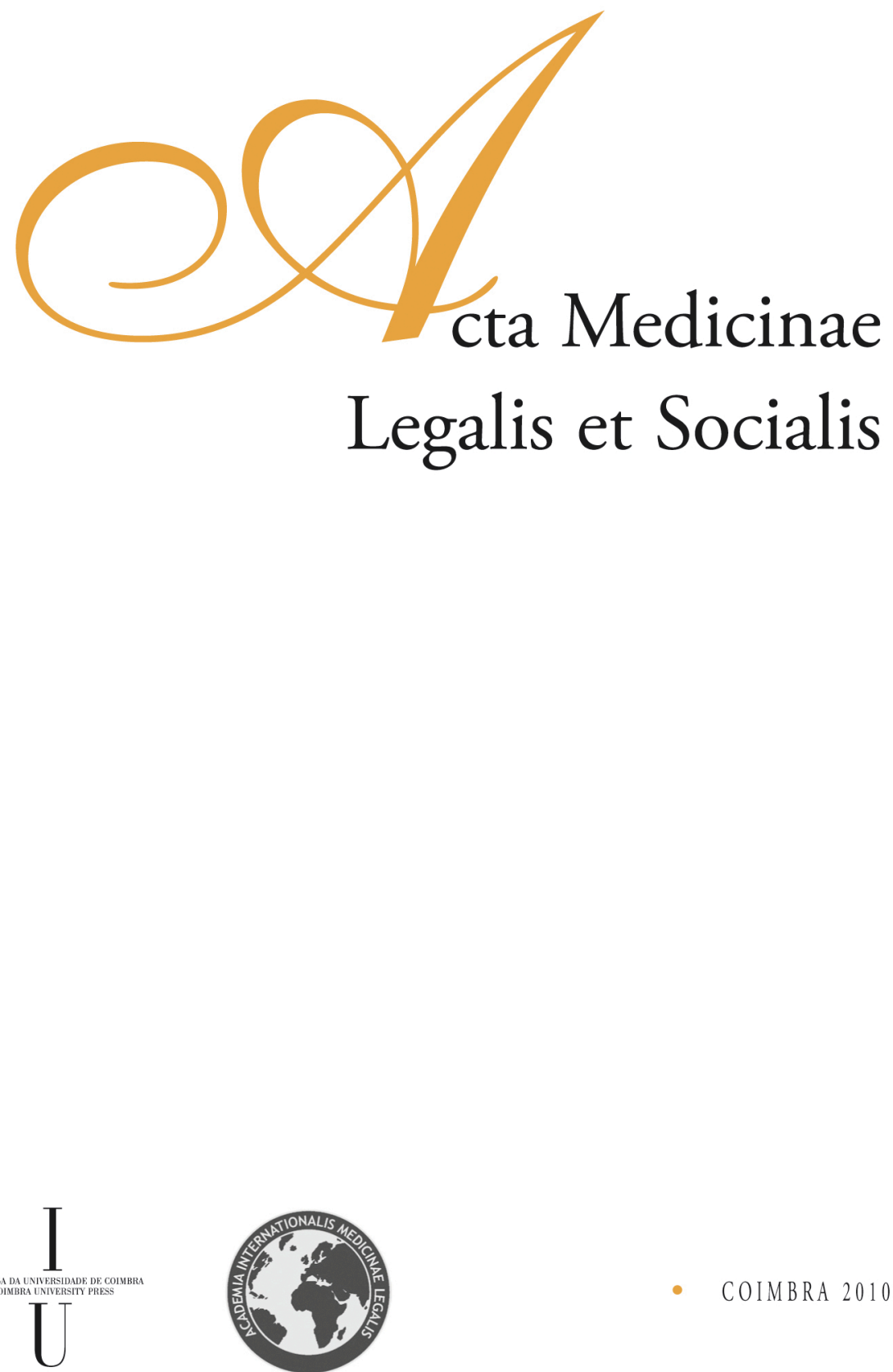
S. Raja ${ }^{1,2}$, B. H. Stuart ${ }^{1,2}$, P. S. Thomas ${ }^{2}$, C. O’Brien ${ }^{3}$

${ }^{1}$ Centre for Forensic Science, University of Technology, Sydney, Australia

${ }^{2}$ Department of Chemistry and Forensic Sciences, University of Technology, Sydney, Australia

${ }^{3}$ Faculty of Science, University of Ontario Institute of Technology, Canada

\title{
PYROLYSIS GAS CHROMATOGRAPHY \\ - MASS SPECTROMETRY ANALYSIS FOR THE ESTIMATION OF PIG BONE AGE FOR FORENSIC APPLICATION
}

\begin{abstract}
The potential of pyrolysis gas chromatography-mass spectrometry (Py-GCMS) as a tool for the estimation of post-mortem age of bones has been investigated. Pig bone specimens prepared under controlled burial conditions in soil were studied and the post-mortem ages ranged from 3 to 48 months. Notable differences were observed in the data produced for younger bone specimens $(<1$ year $)$ compared to specimens of greater post-mortem age ( $>1$ year). Py-GCMS also demonstrates a relationship of particular peak ratios with the age of bones. The ratios of peaks in the pyrograms were examined and it was demonstrated that the ratios of certain pairs of peaks increase as the bone age increases.
\end{abstract}

\section{Introduction}

Bone is a complex composite material consisting of approximately $10 \%$ water, $30 \%$ organic phase and $60 \%$ inorganic material. Although the chemistry of archaeological bones has been more widely studied, the structures of lesser aged bones such as those that are encountered in a forensic context, have not been as well studied. However, in a recent study, it was demonstrated that changes to relatively young bones can be detected using techniques that examine the decomposition of the organic phase of bone [1,2]. Thermogravimetric analysis (TGA) combined with mass spectrometry (MS) was used to examine young pig bones and demonstrated that TG-MS is a technique sensitive to the age of the bones and the environment in which the bones decomposed.

Pyrolysis gas chromatography - mass spectrometry (Py-GCMS) is established as an effective technique for the characterisation of complex organic molecules. This technique has the added attraction for forensic practitioners of being a cost-effective method that provides good discrimination, involves minimal sample preparation and is able to detect very small quantities of material. Py-GCMS is recognised as a useful tool in particular areas of forensic analysis, including automotive paints [3], tire trace analysis [4,5], adhesives [6,7], lubricants [8] and fingerprints [9]. One study that used GCMS to examine the pyrolysis products of animal bone found that the major decomposition products are nitriles, pyridines, pyrroles and amides [10]. 
In the current study, Py-GCMS was used to pyrolyse the organic phase of the bone and compare the pyrolysis products of the bone samples. A series of pig bones of different post-mortem ages were studied and changes to the data associated with age were investigated.

\section{Materials and methods}

\section{Bone samples}

Bone specimens with post-mortem ages ranging from 3 months to 7 years were obtained from pigs buried for different time periods. All samples were flat rib bones from female pigs (Sus scrofa) sourced from the same farm with an identical diet and weighing 40-45 kg. The carcasses were buried in soil at $60 \mathrm{~cm}$ below the surface for the designated amount of time. The average ambient temperature was $25^{\circ} \mathrm{C}$ and a soil $\mathrm{pH} 5$. After exhumation the bones were stored in sealed in plastic bags at $4^{\circ} \mathrm{C}$ prior to analysis.

The compact bone specimens were cleaned by scraping of the surface with a scalpel to remove fatty bone marrow from the interior and any residues from the exterior of the specimens [11]. The bones were mechanically sliced using a Buehler IsoMet low speed diamond saw into $2 \mathrm{~mm}$ thickness slices. Each sample was dried in a vacuum oven at $50^{\circ} \mathrm{C}$ for $2.5 \mathrm{~h}$ to remove moisture. The slices were then cut in half using a scalpel.

\section{Pyrolysis GCMS}

Pyrolysis was carried out using a Shimadzu Furnace Pyrolyser- 4 a set at $450^{\circ} \mathrm{C}$. The pyrolyser was mounted on the split injector of a Shimadzu GC-17A gas chromatograph coupled to a Shimadzu GCMS-QP5050A mass spectrometer. The chromatographic column used was a J \& W Scientific DB-5MS column, $60 \mathrm{~m}$ in length with an internal diameter of $0.25 \mathrm{~mm}$. Data analysis was performed using Shimadzu Class-5000 software and the mass spectra were identified using a NIST62 library database.

\section{Results and discussion}

A comparison of the results of replicates of the same sample and different bone samples of the same age was carried out in order to determine the reproducibility of the pyrograms. The retention times, peak patterns and the compound represented by each peak were compared and found to be very similar in each run of same age samples.

Figure 1 illustrates the pyrogram of a bone sample of age 3 months and shows the characteristic pattern observed by the younger bones studied. All pyrograms show a large peak at a retention time of $1 \mathrm{~min}$. Prominent peaks are also observed in the 17 $25 \mathrm{~min}$ region. In addition, the younger samples have significant peaks in the 29-30 min region. The peak at $20 \mathrm{~min}$ is a single peak in the younger samples.

A comparison of the peak patterns of the pyrograms of different bone age samples demonstrates a difference between the patterns of the younger bones $(<1$ year) and those of the older bones ( $>1$ year). Figure 2 shows the pyrogram of bone of age 48 months and illustrates the pattern difference due to age. The older samples do not 
have significant peaks in the $29-30 \mathrm{~min}$ region. The peak at $20 \mathrm{~min}$ is also split into two components for samples of greater age. Based on a comparison with the library database, the splitting peak appears to represent the presence of two organic compounds, pentanal and 1,1,3,4-tetramethylcyclopentane, eluting at very close retention times.

The data were normalised by calculating the ratios of significant peaks and any trends were observed. The peaks near $20 \mathrm{~min}$ were selected as it showed changes in its splitting pattern. The peaks at 19, 22 and 23 min demonstrate observable changes in peak heights with relation to age. In each pyrogram, the height of the peak at 19 min was divided by the height of the peak at $20 \mathrm{~min}$ to obtain a peak ratio. Similarly, the height of the peak at $22 \mathrm{~min}$ was divided by the height of the peak at $23 \mathrm{~min}$ to obtain a second peak ratio. The peak ratios with their corresponding post-mortem ages are presented in Figure 3. This plot demonstrates that there is a relationship between peak ratios and age, and as age increases, so do the peak ratios.

\section{Conclusions}

For all samples studied using Py-GCMS, the most prominent peaks occur in the 17-25 min region. Only the younger samples showed significant peaks in the 29-30 min region. A peak at $20 \mathrm{~min}$ is a single peak in the younger samples, but shows splitting in the older samples. A comparison of particular peak ratios with age demonstrates that as post-mortem age increases, so do the peak ratios.

There is potential for this technique to be used for the estimation of post-mortem age of bones. Further work is being carried out to develop the potential of this technique. A detailed investigation of the reproduction of the data is being undertaken. Analysis involving pattern recognition of the data is being carried out in order to establish a simple method of determining forensic bone age.

\section{References}

[1] A ONISHI, PS THOMAS, BH STUART, JP GUERBOIS, SL FORBES, TG-MS analysis of the thermal decomposition of pig bone for forensic applications, J. Therm. Anal. Cal. 92, 87-90, 2008.

[2] S RAJA, BH STUART, PS THOMAS, JP GUERBOIS, C O'BRIEN, The estimation of pig bone age for forensic application using thermogravimetric analysis, J. Therm. Anal. Cal., 98, 173-176, 2009.

[6] J HUTTUNEN, C AUSTIN, M DAWSON, C ROUX, J ROBERTSON, Physical evidence in drug intelligence, Part 1: rationale based on hierarchic distribution of drugs using pyrolysis gas chromatography - mass spectrometry as an example, Aust. J. Forensic Sci. 39, 93-106, 2007.

[9] A RICHMOND-AYLOR, S BELL, P CALLERY, K MORRIS, Thermal degradation analysis of amino acids in fingerprint residue by pyrolysis GCMS to develop new latent fingerprint developing reagents, J. Forensic Sci. 52, 380-382, 2007.

[3] J ZIEBA-PALUS, G ZADORA, JM MILCZAREK, P KOSCIELNIAK, Pyrolysis gas chromatography - mass spectrometry analysis as a useful tool in forensic examination of automotive paint traces, J. Chromatograph. A 1179, 41-46, 2008. 
[5] G SARKISSIAN, The analysis of tire rubber traces collected after braking incidents using pyrolysis gas chromatography - mass spectrometry, J. Forensic Sci. 52, 1050-1056, 2007.

[4] G SARKISSIAN, J KEEGAN, E DU PASQUIER, JP DEPRIESTER, P ROUSSELOT, The analysis of tires and tire traces using FTIR and Py-GCMS, Can. Soc. Forensic Sci. J. 37, 19-37, 2004.

[7] NL BAKOWSKI, EC BENDER, TO MUNSON, Comparison and identification of adhesives used in improvised explosive devices by pyrolysis capillary column gas chromatography mass spectrometry, J. Anal. Appl. Pyrolysis 8, 483-492, 1985.

[8] GP CAMPBELL, AL GORDON, Analysis of condom lubricants for forensic casework, J. Forensic Sci. 52, 630-642, 2007.

[10] B PUREVSUREN, B AVID, T GERELMAA, Y DAVAAJAV, TJ MORGAN, AA HEROD, R KANDIYOTI, The characterisation of tar from the pyrolysis of animal bones, Fuel 83, 799-805, 2004.

[11] A ONISHI, PS THOMAS, BH STUART, JP GUERBOIS AND S FORBES, TG-MS characterisation of pig bone in an inert atmosphere, J. Therm. Anal. Cal. 88, 405-409, 2007.

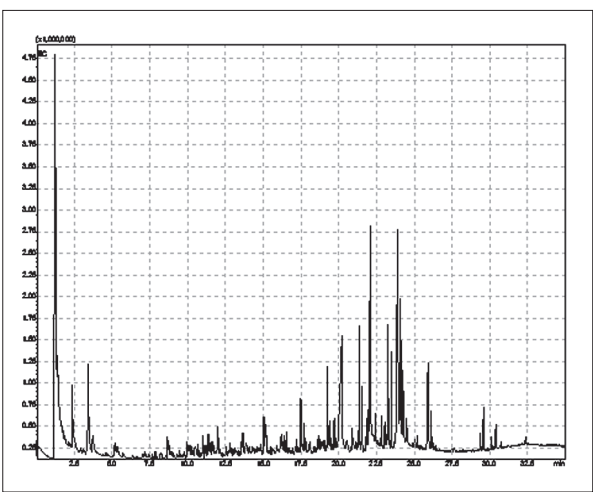

Figure 1 - Pyrogram of bone aged 3 months.

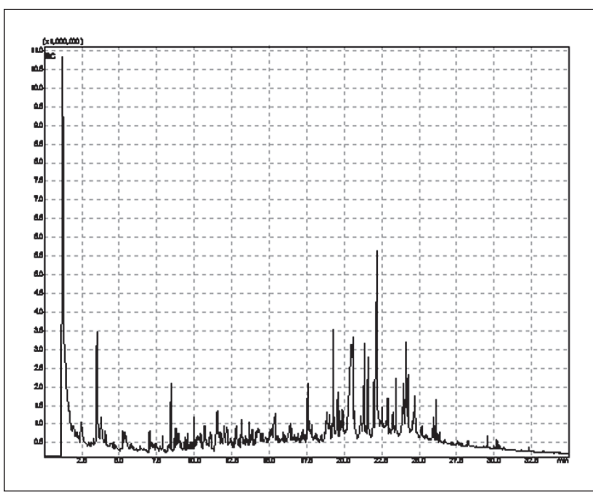

Figure 2 - Pyrogram of bone aged 48 months.

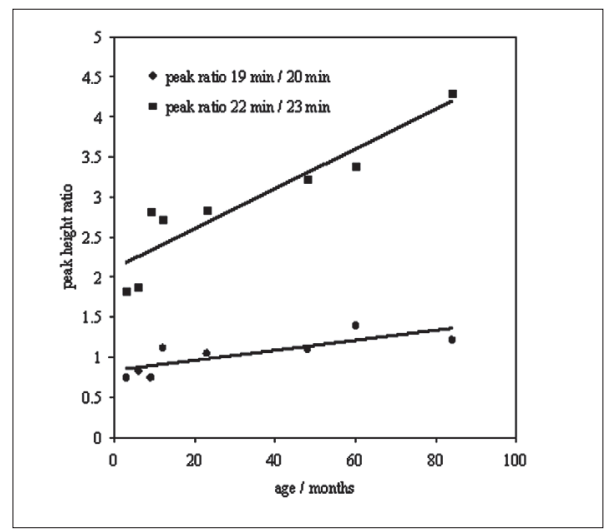

Figure 3 - Peak height ratios as a function of post-mortem age. 